University of Windsor

Scholarship at UWindsor

$11-16-2017$

\title{
Combining ballast water treatment and ballast water exchange: Reducing colonization pressure and propagule pressure of phytoplankton organisms
}

\author{
Esteban M. Paolucci \\ Leila Ron \\ Hugh J. Maclssaac \\ University of Windsor
}

Follow this and additional works at: https://scholar.uwindsor.ca/biologypub

Part of the Biology Commons

\section{Recommended Citation}

Paolucci, Esteban M.; Ron, Leila; and Maclssaac, Hugh J., "Combining ballast water treatment and ballast water exchange: Reducing colonization pressure and propagule pressure of phytoplankton organisms" (2017). Aquatic Ecosystem Health \& Management, 20, 4, 369-377.

https://scholar.uwindsor.ca/biologypub/1189

This Article is brought to you for free and open access by the Department of Biological Sciences at Scholarship at UWindsor. It has been accepted for inclusion in Biological Sciences Publications by an authorized administrator of Scholarship at UWindsor. For more information, please contact scholarship@uwindsor.ca. 
Title: Ships' Ballast Water Treatment by Chlorination Can Generate Toxic Trihalomethanes Authors: Marco R. Hernandez ${ }^{1}$, Nargis Ismail ${ }^{1}$, Ken G. Drouillard ${ }^{1}$, and Hugh J. MacIsaac ${ }^{1}$ Affiliation footnote: ${ }^{1}$ Great Lakes Institute for Environmental Research, University of Windsor, Windsor, ON, Canada, N9B 3P4. Corresponding author: hernand2@uwindsor.ca.

\section{Abstract}

The International Maritime Organization (IMO) will enforce a new abundance-based performance standard for ballast water in September, 2017. Strong oxidants, like chlorine, have been proposed as a method for achieving this standard. However chlorine treatment of ballast water can produce hazardous trihalomethanes. We assessed maximum trihalomethane production from one chlorine dose for three types of ballast water (fresh, brackish and marine) and three levels of total organic carbon (TOC) concentration (natural, filtered, enhanced). While the current standard test considers a five day voyage, there is a high possibility of shorter trips and sudden change of plans that will release treated waters in the environment. Water source and TOC significantly affected trihalomethane production, with the highest amounts generated in brackish waters and enhanced TOC concentration. The concentration of brominated trihalomethanes increased from background levels and was highest in brackish water, followed by marine and fresh water.

Keywords: THMs, seawater, brackish, freshwater, TOC, IMO D-2 standard

Vessels use ballast water to preserve buoyancy and maneuverability (Carlton 1987); by design, ballast tanks hold a volume sufficient to equal the tonnage of dry cargo (IMO 2008a). It is estimated that three to five billion tons of ballast water are transported every year (Globallast IMO 2015). Large vessels like bulk carriers and tankers can discharge between 15,000 and $113,000 \mathrm{~m} 3$ of treated ballast water in a single event, thereby posing an invasion risk for recipient ports. New global regulations for ballast water management will be globally implemented beginning September, 2017. These regulations are designed to reduce the movement of nonindigenous species by setting numerical limits for abundance of two planktonic groups and three health-related bacteria of concern (IMO 2016). Different alternatives to achieve these limits exist, including use of strong oxidants such as chlorine (e.g. Werschkun et al. 2012; Zhang et al. 2013). Chlorine may be applied to ballast water either directly or indirectly via in situ electrochlorination of sea water.

Chlorine is the most widely used chemical for disinfection of fresh water, as it eliminates active pathogens. However, chlorine treatment of water is associated with undesirable by-products, some of which have carcinogenic effects (Boorman et al. 1999). Trihalomethanes (THMs), which result when three halogen atoms are substituted for hydrogen atoms in the methane molecule, are the most commonly observed by-product (Budziak et al. 2007).

THMs formation depends on the availability of both chlorine and natural organic matter (NOM). Limiting production of THMs by pre-treatment to reduce NOMs is a common practice in public utilities (Bull et al. 1995). This capability does not extend to ballast water, where large volumes of water are loaded and discharged, and little space exists for on-board pre-treatment.

Consequently, ballast water treatment has focused on control of the oxidant dose (Tsolaki et al . 2010; Paolucci et al. 2015). Salinity of ballast water varies according to the geographic location where it is loaded. 
contain particulate organic carbon (POC) produced by plants and animals. The availability of NOM and POC in water plays a key role in the quantity of THMs generated; however, there is a large list of organic compounds that constitute NOM and POC in water, with the compounds varying with the water source (Liu et al. 2015). The sum of DOC and POC equals total organic carbon (TOC) and is typically used as a proxy for the potential reactive pool for THMs generation (Bruchet et al. 1990; Singer 1999).

THMs are continuously produced if NOM is present and the halogen supply is not exhausted (Stack et al. 2000). The most abundant halogen used in ballast treatment is chlorine because it is inexpensive and can be readily added from sources such as sodium hypochlorite $(\mathrm{NaClO})$. If the ballast is fresh water, $\mathrm{CHCl}_{3}$ may constitute the most abundant THM, based upon utility plant experience (Ivahnenko and Zogorski 2006). However, THMs abundance and composition changes in the presence of bromine. High concentrations of bromine result in brominated THMs even when chlorine is added as the active substance of disinfection (Bull et al. 1995). Ballast from brackish and marine waters may produce brominated THMs owing to the higher bromine content of these water sources (Ged and Boyer 2014). Speciation of THMs occurs when bromine is present in the water, leading to the formation of $\mathrm{CHCl}_{2} \mathrm{Br}, \mathrm{CHCIBr}_{2}$, and $\mathrm{CHBr}_{3}$, with the sum of these plus $\mathrm{CHCl}_{3}$ equalling total THMS (TTHMs; Singer 1999). The ratio of chlorinated to brominated species can be estimated based on molar ratios and then extrapolated using probability models when analysis is limited to final concentration of TTHMs and not initial doses of chlorine and bromine (Chang et al. 2001).

Here we evaluate potential TTHMs production in ballast water treated with chlorine at doses recommended for use to reduce target organisms in ballast water (see Paolucci et al. 2015), specifically exploring the effects of both water salinity and NOM. Experiments were performed using natural water sources representative of freshwater and brackish waters from shipping ports and marine water derived from a ballast sample. In addition, we augmented samples with humic acids to explore effects of NOM concentration on THM generation.

\section{Materials and Methods}

Water samples were collected from two different ports and one vessel according to their salinity as a follow-up to a larger ballast water treatment experiment (see Paolucci et al. 2015). Sampled water included fresh water (0.1 practical salinity units; PSU) from Trois Rivières, Québec and brackish water (11.3 PSU) from Port Alfred, Québec, and marine water (34.0 PSU) was collected from a ballast tank of a general cargo vessel whose water was exchanged in the North Atlantic region ( $38^{\circ} 08.7^{\prime} \mathrm{N}, 67^{\circ} 23.1^{\prime} \mathrm{W}$ ) according to its ballast water management record. All samples were kept in the dark at $4^{\circ} \mathrm{C}$ until day of analysis. Water in amber glass bottles at ambient temperature was used hereafter to mimic light exposure in a ballast tank.

The experimental design was full factorial with two fixed factors: source of water (according to salinity) and organic matter content. Three conditions for organic content were tested: i) natural condition (water as it was collected); ii) removal by filtration (POC and other suspended solids were removed) with a $0.45 \mu \mathrm{m}$ glass fibre filter; and iii) enrichment with humic acid (HUMICan 100, AgroCare Canada) to increase content of TOC to $25 \mathrm{mg} \mathrm{L}^{-1}$. The resulting $3 \times 3$ combinations were prepared in a $500 \mathrm{~mL}$ sterilized, amber glass bottle with a Teflon lined cap. Five hundred $\mathrm{mL}$ were measured with a volumetric flask and dosed (single pulse) to $10 \mathrm{mg} \mathrm{Cl} \mathrm{L-}$ ${ }^{1}$ using commercial pool bleach (sodium hypochlorite 10\%, Pool Sanitizer, Cul-Mac Industries, Inc., Wayne, MI, USA) at $10 \%$ weight-to-weight $(\mathrm{w} / \mathrm{w})$ solution. All nine treatments $(3 \times 3$ combinations) were analyzed in triplicate ( 3 replicates per treatment) across three time intervals 
( $\mathrm{t} 1 \approx 1$ hour, $\mathrm{t} 2 \approx 5$ hours, and $\mathrm{t} 3 \approx 25-26$ hours) to assess THMs maximum production. TOC was measured prior to incubation using an in-line TOC analyzer (Shimadzu, model VCSH, Kyoto JP) with a detection limit of $1 \mathrm{mg} \mathrm{L}^{-1}$ and chlorine (estimated detection limit $0.1 \mu \mathrm{g} \mathrm{L}^{-1}$ ) using a Hach Pocket ColorimeterTM II (Hach, Loveland, CO, USA).

At sampling, THMs were extracted from water samples using the method of headspace solidphase microextraction (SPME) followed by analysis by GC-MSD (Stack et al. 2000; Zhao et al. 2004). A SPME fiber (75 $\mathrm{m}$ CAR/PDMS, 24 Ga.; Supelco, Bellefonte, PA, USA,), mounted in a manual holder, was used to transfer the extracted analytes. The fibre was conditioned at $300^{\circ} \mathrm{C}$ for $5 \mathrm{~min}$ before and after each extraction. SPME extraction was performed by transferring $20 \mathrm{~g}$ of water sample from a given incubation vessel into a precleaned amber VOA vial with screw cap and PTFE/silicone septum (EPA VO vials, Supelco part \# 23189), containing 7.2g of NaCl and spiked with a mix of recovery surrogate standard solution containing p-bromofluorobenzene and d8-Toluene [CPL-PS-4X, AccuStandard, New Haven, CT, USA (concentration: $2 \mu \mathrm{g} \mathrm{mL}^{-1}$; $10 \mu \mathrm{L})]$. The sample was vortexed for $1 \mathrm{~min}$, following which a SPME needle (protecting fibre) was slid through the pierced septum and into the vial. Needle depth was adjusted to keep the fibre above the liquid layer in the headspace environment. The SPME extraction was initiated after exposing the fibre into the headspace and heating the vial indirectly at $45^{\circ} \mathrm{C} \pm 1{ }^{\circ} \mathrm{C}$ with constant stirring at $300 \mathrm{rpm}$ for $20 \mathrm{~min}$. Our methods differed slightly from those of Stack et al. (2000) and Zhao et al. (2004), the former because we used moderate stirring for $20 \mathrm{~min}$ as opposed to low stirring for a longer period, and the latter because we increased temperature. Volatiles were absorbed/adsorbed to the fibre and concentrated, followed by retraction of fibre into the needle. Thermal desorption of THMs from the fibre occurred when the needle was directly introduced to the GC inlet, followed by the extension of the fibre from the needle and the introduction of the fibre into the hot GC inlet.

Analytes were identified and quantified using a gas chromatograph with a mass selective detector (GC/MSD) (Hewlett Packard HP 6890/5973, Wilmington, DE, USA) equipped with a capillary column [VF-624ms; 30m x $0.25 \mathrm{~mm}$ I.D. x $1.4 \mu \mathrm{m}$ film thickness (Agilent J\&W, Santa Clara, CA, USA)]. The inlet was set at $250^{\circ} \mathrm{C}$ in a splitless mode and carrier gas (UHP) at a flow rate of $0.8 \mathrm{~mL} \mathrm{~min}^{-1}$ with column head pressure 4.8 psi. The MSD operated in EI SIM mode. Oven temperature was set at $40^{\circ} \mathrm{C}$ for an initial time of $2.0 \mathrm{~min}$ and increased at a rate of $7^{\circ} \mathrm{C}$ $\mathrm{min}^{-1}$ and held at $130^{\circ} \mathrm{C}$ for $1.0 \mathrm{~min}$. The total analysis time was $15.86 \mathrm{~min}$ with equilibration time at $0.5 \mathrm{~min}$. Calibration was carried out with the same procedure replacing the sample water with $20 \mathrm{~mL}$ of buffer solution [sodium chloride (360g) in Milli-Q water (1L) fixed at pH 2.0 with ortho-phosphoric acid (85\% weight/weight)].

Known concentrations of THMs were loaded into $20 \mathrm{~g}$ of water using the THM standard mix (M-501-10X, AccuStandard, New Haven, CT, USA) to generate a calibration curve. Method detection limits (MDLs) for the THMs were based on a signal-to-noise ratio $(\mathrm{S} / \mathrm{N} * 5)$ at low concentration and were between 0.04 to $0.05 \mu \mathrm{g} \mathrm{L}^{-1}$ for $\mathrm{CHCl}_{3}, \mathrm{CHBrCl}_{2}, \mathrm{CHBr}_{2} \mathrm{Cl}$ and $\mathrm{CHBr}_{3}$. The recovery rate for our surrogate was $94.3 \%$. However, it was not used in MDLs determination because it was within the acceptable range for volatiles.

Table 1. Mean (SD) total organic carbon (TOC; $\mathrm{mg} \mathrm{L}^{-1}$ ), $\mathrm{pH}$, salinity (PSU) and TTHMs (mg L$\left.{ }^{1}\right)$ measured before dosing samples with chlorine.

\begin{tabular}{|l|c|c|c|c|c|c|}
\hline Water Source & Natural & Filtered & Enriched & $\mathrm{pH}$ & Salinity & TTHMs \\
\hline Fresh & $15.6(0.8)$ & $7.3(0.0)$ & $23.9(3.2)$ & $8.2(0.2)$ & $0.1(0.0)$ & $0(0)$ \\
\hline Brackish & $11.4(0.4)$ & $8.6(0.2)$ & $26.1(2.4)$ & $7.2(0.2)$ & $11.3(0.2)$ & $0(0)$ \\
\hline
\end{tabular}




\begin{tabular}{|l|l|l|l|l|l|l|}
\hline Marine & $18.8(1.8)$ & $11.4(0.1)$ & $22.1(2.1)$ & $7.8(0.1)$ & $34.0(0.1)$ & $0(0)$ \\
\hline
\end{tabular}
A univariate general linear model was conducted on the production of TTHMs using two fixed factors (water source and TOC content), and a covariate (time after dose). We also tested for an interaction between the fixed factors. Additionally, we performed an independent sample t-test for TOC content between natural and filtered for all sources of water. All statistical analyses were carried out with IBM SPSS Statistics version 23 (IBM Corp., Armonk, OK, USA).

\section{Results and Discussion}

Filtered and natural TOC concentrations were low in both natural and filtered water for fresh and brackish waters, and slightly higher in marine waters (Table 1). There were no detectable concentrations of TTHMs in vessels prior to chlorine addition in vessels (Table 1). Total THM production varied significantly by water source and by TOC content at the outset of the experiment, and by an interaction of these parameters (Table 2). Fresh water produced on average less TTHMs than any other source, while marine water produced an intermediate amount of TTHMs and brackish water the highest amount (Table 2, Fig. 1).

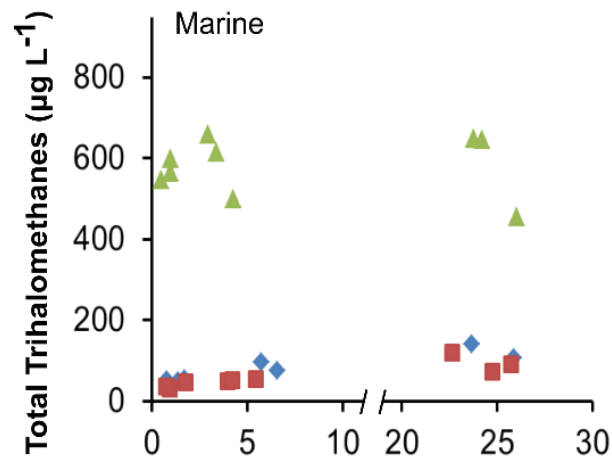

Time (hours) analyzed. Individual panels display water types commonly used as ballast, and the series depict different TOC concentrations.

Enrichment of TOC increased TTHMs production for fresh and marine waters but not for brackish water (Table 2; Fig. 1). Filtering significantly reduced TOC concentration versus natural conditions $(\mathrm{t}=5.17 \mathrm{df}=16$, and $\mathrm{p}<0.001)$. Although non-significant, filtered samples yielded the highest production of TTHMs for brackish water (Table 2; Fig. 2).

TTHMs maximum production was achieved very quickly (i.e. within 1 hour) and was sustained over the 24-hour follow-up measure in all TOC concentrations for fresh and marine water (Fig. 1, right and left panels). Brackish water almost doubled TTHMs in the first hours after dose for natural and filtered concentrations, and sustained the same levels in the enriched concentration (Fig. 1, middle panel).

$\mathrm{CHCl}_{3}$ was the major constituent of TTHMs in fresh water, whereas brackish or marine water treatments had a higher ratio of brominated to chlorinated species of THMs owing to the very low presence of bromine in fresh water (Table 2). Most production in natural or filtered fresh water was by $\mathrm{CHBrCl}_{2}$ (Table 2). By contrast, marine and brackish water produced more $\mathrm{CHBr}_{3}$ but under different conditions, with the former being greatest in the enhanced TOC concentration and the latter in natural and filtered concentrations (Table 2).

The World Health Organization (WHO) limits TTHMs to $200 \mu \mathrm{g} \mathrm{L} \mathrm{L}^{-1}$; with individual conditions for chloroform $\left(\mathrm{CHCl}_{3}\right)$ to $200 \mu \mathrm{g} \mathrm{L}^{-1}$, bromoform $\left(\mathrm{CHBr}_{3}\right)$ to $100 \mu \mathrm{g} \mathrm{L} \mathrm{L}^{-1}$, dibromochloromethane 
$\left(\mathrm{CHClBr}_{2}\right)$ to $100 \mu \mathrm{g} \mathrm{L}^{-1}$, and bromodichloromethane $\left(\mathrm{CHCl}_{2} \mathrm{Br}\right)$ to $60 \mu \mathrm{g} \mathrm{L}-1$ (Stack et al. 2000). We found concentrations of TTHMs in fresh water ballast for natural and filtered concentrations were well below the $200 \mu \mathrm{g} \mathrm{L}^{-1}$ limit, and thus compliant with WHO regulations for continental waters (Agus et al. 2009; Werschkun et al. 2012). It is likely that a source of fresh ballast water with a maximum TOC concentration of $16 \mathrm{mg} \mathrm{L}^{-1}$ would produce similar or lower concentrations for TTHMs with doses of $\mathrm{Cl}^{-1} \leq 10 \mathrm{mg} \cdot \mathrm{L}^{-1}$.

Similarly, we expect that marine water will be below permissible limits set by WHO regulations for TTHMs. However, under conditions of enhanced TOC concentration, we anticipate that production of TTHMs would increase greatly (Table 2) and possibly exceed these regulations. Production of TTHMs in enriched marine water was almost 10 times higher than in filtered or natural water (Table 2). It is apparent that the largest limiting factor for THMs production in marine ballast water used in this experiment is NOM in the water.

Brackish water produced less TTHMs under enrichment than under natural or filtered conditions. We propose that an inhibitor may have prevented the oxidation process in water collected at Port Alfred. Further, we propose that some macromolecules may sequester chlorine in the natural condition, because filtering removes suspended particles above $0.45 \mu \mathrm{m}$ in size. It has been documented that ammonia reduced THMs production during chlorination despite the presence of humic substances (Amy et al. 1984). High production of TTHMs in brackish versus marine or fresh water has been documented in at least five ballast water treatment systems (OceanSaver, CleanBallast, Greenship, TG, OceanGuard) (Werschkun et al. 2012). Similar results were also found when the OceanGuard system was tested on land, with $\mathrm{CHBr}_{3}$ accounting for almost $90 \%$ of the total $670 \mu \mathrm{g} \mathrm{L}^{-1} \mathrm{TTHM}$ produced (Werschkun et al. 2012).

Table 2. Mean (SD) production of THMs $\left(\mu \mathrm{g} \mathrm{L}^{-1}\right)$ in each combination of fixed factors.

\begin{tabular}{|l|l|r|r|r|r|r|}
\hline Water source & \multicolumn{1}{|c|}{ TOC } & \multicolumn{1}{c|}{$\mathrm{CHCl}_{3}$} & \multicolumn{1}{|c|}{$\mathrm{CHBrCl}_{2}$} & \multicolumn{1}{c|}{$\mathrm{CHBr}_{2} \mathrm{Cl}$} & \multicolumn{1}{c|}{$\mathrm{CHBr}_{3}$} & \multicolumn{1}{c|}{ Total THMs } \\
\hline Marine & Enriched & $0.9(0.3)$ & $15.0(0.5)$ & $32.9(7.0)$ & $545.6(64.2)$ & $581.1(71.3)$ \\
\hline Marine & Filtered & $1.3(0.9)$ & $5.7(0.6)$ & $7.7(10.7)$ & $75.7(32.7)$ & $86.6(33.1)$ \\
\hline Marine & Natural & $0.6(0.1)$ & $2.2(0.1)$ & $3.4(1.2)$ & $57.4(27.3)$ & $61.6(28.6)$ \\
\hline Brackish & Enriched & $2.7(1.4)$ & $128.1(5.3)$ & $73.5(11.9)$ & $341.8(27.3)$ & $432.2(25.6)$ \\
\hline Brackish & Filtered & $1.6(0.9)$ & $21.2(0.4)$ & $34.7(6.0)$ & $633.4(163.1)$ & $672.0(168.1)$ \\
\hline Brackish & Natural & $0.8(0.5)$ & $14.7(0.5)$ & $28.1(7.4)$ & $575.0(187.5)$ & $605.5(194.2)$ \\
\hline Fresh & Enriched & $169.8(73.9)$ & $113.0(6.2)$ & $14.9(20.4)$ & $43.3(65.5)$ & $240.5(67.2)$ \\
\hline Fresh & Filtered & $31.9(17.5)$ & $97.6(4.7)$ & $7.4(2.6)$ & $25.4(8.7)$ & $75.6(21.6)$ \\
\hline Fresh & Natural & $40.2(21.5)$ & $119.4(2.8)$ & $10.0(4.0)$ & $33.3(15.0)$ & $96.8(14.7)$ \\
\hline
\end{tabular}

Experiments with chlorination in marine water, as a means to control biofouling, used doses from 0.5 to $1.5 \mu \mathrm{g} \mathrm{L}^{-1}$ and resulted in TTHMs concentrations of 2.5 to $18.5 \mu \mathrm{g} \mathrm{L}^{-1}$ (Boudjellaba et al. 2016). However, the IMO D-2 performance standard targets two planktonic groups that will require a larger dose to achieve lethality in larger organisms (Gregg et al. 2009). Our TTHM production results for marine water were an order of magnitude greater than those of Boudjellaba et al. (2016). Other studies that have evaluated differences in TTHM production using nearshore and deep-ocean waters revealed that TTHM production differed by orders of magnitude, with nearshore water having the highest TTHM production (Fabbricino and Korshin 2005). Werschkun et al. (2012) reported that three commercial ballast water treatment systems (CleanBallast, TG and OceanGuard), tested with marine water and a lower chlorine dose, experienced TTHMs production just below $200 \mu \mathrm{g} \mathrm{L} \mathrm{L}^{-1}$ over a five day cycle (as required by IMO G9; IMO 2008b). OceanSaver produced relatively less TTHMs, yielding results similar to ours 
(Fig. 1 left panel). Cowman and Singer (1996) documented a shift of brominated species in disinfection by-products, where hypochlorous acid continuously integrated bromide into THM formation. The free chloride from the completion of this reaction restarts the process. Marine water produced more TTHMs when enriched compared with fresh water. Symons et al. (1993) found that chlorine (as low as $3 \mathrm{mg} \mathrm{L}^{-1}$ ) in the presence of precursors (DOC and bromide) in fresh water, will promote production of brominated species until complete exhaustion of one precursor. In contrast, production in fresh water will stop when hypochlorous acid no longer can react with organic matter.

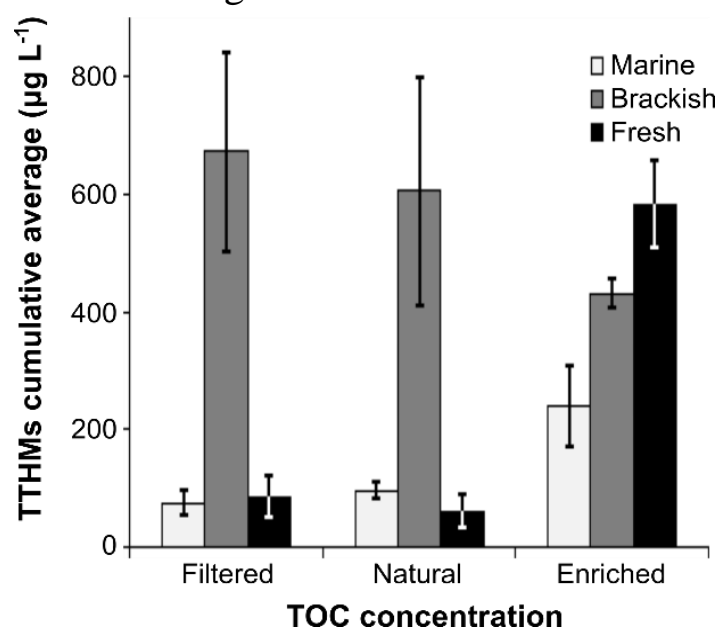

Fig. 2 TTHMs cumulative average and standard deviation $\left(\mu \mathrm{g} \mathrm{L}^{-1}\right)$ for all TOC concentrations and ballast water sources.

Chlorination is an effective alternative to ballast water exchange under the new IMO ballast water standard. Bench-scale experiments like ours allow inferences to be made regarding patterns and trends, though care must be taken when extrapolating to the field. Paim et al. (2007) spiked fresh water with humic acids to $23.7 \mathrm{mg} \mathrm{L}^{-1}$ and, using a $5 \mu \mathrm{g} \mathrm{L}^{-1}$ chlorine dose, reported a maximum production of $\mathrm{CHCl}_{3}$ of $18 \mu \mathrm{g} \mathrm{L}^{-1}$. Our experiments with fresh water, conducted under laboratory conditions and $10 \mu \mathrm{g} \mathrm{L}^{-1} \mathrm{Cl}^{-1}$ and $23.9 \mathrm{mg} \mathrm{L}^{-1} \mathrm{TOC}$, revealed much higher production of TTHMs (Fig. 1) during the first hours. This large difference might stem from the higher chlorine dose and its apparent immediate impact on $\mathrm{CHCl}_{3}$ production. It is apparent that filtering will remove the particulate fraction, yet it had little or a net positive effect on subsequent TTHMs production because the dissolved fraction of organic carbon was involved in reactions that produced TTHMs. Liu et al. (2015) observed that only four species of organic carbon (glycolic, alginic, citric, humic acids and urea) enhanced TTHM production. While it will be difficult for crew and port authorities to analyze what species of organic carbon is in the water, the option exists to adjust the dose. In addition, it is possible to track free chlorine in real time using electronic sensors in the tanks (Zimmer-Faust et al. 2014).

This study assessed the importance of ballast water source and its organic carbon content to production of TTHMs. By IMO convention (IMO 2008b), analyses of TTHMs are only made during final discharge of ballast water; our study reveals patterns of TTHM production and attenuation priot to discharge. We observed clear differences in TTHM production in brackish, fresh and marine water, which has strong implications for where ballast water should be loaded and its likely generation of TTHMs. Ballast water loaded in freshwater ports - even if TOC load is high - may pose less risk of TTHM production than that loaded in brackish or marine water. However, many global ports are brackish or marine (Werschkun et al. 2014), thus by-product 
generation of TTHMs may pose a problem, particularly in carbon-enriched marine or filtered brackish water for voyages shorter than five days (see guidelines G8 and G9; IMO 2008a, b). Our results suggest that if treated ballast water is discharged within the first two days there is a risk of releasing sufficient TTHMs to cause environmental harm.

\section{Acknowledgements}

We thank the captain and crew of the Helen $\mathrm{C}$ vessel for allowing us to collect ballast samples during port operations, C. van Overdijik, B. Middleton, S. Collins and S. Jarison for valuable assistance. We also want to thank the editor, Dr. Erin Bennett, and two anonymous reviewers who provided valuable comments to improve this work. This study was funded by a CONACYT graduate scholarship to MRH and NSERC Discovery grant and Canada Research Chair to HJM.

\section{References}

Agus E, Voutchkov N, Sedlak, DL (2009) Disinfection by-products and their potential impact on the quality of water produced by desalination systems: a literature review. Desalination 237:214237

Amy GL, Chadik PA, King PH, Cooper WJ (1984) Chlorine utilization during trihalomethane formation in the presence of ammonia and bromide. Environ Sci Technol 18:781-786 Boudjellaba D, Dron J, Revenko G, Démelas C, Boudenne JL (2016) Chlorination by-product concentration levels in seawater and fish of an industrialised bay (Gulf of Fos, France) exposed to multiple chlorinated effluents. Sci Total Environ 541:391-399

Boorman GA, Dellarco V, Dunnick JK, Chapin RE, Hunter S, Hauchman F, Gardner H, Cox M, Sills RC (1999) Drinking water disinfection byproducts: Review and approach to toxicity evaluation. Environ Health Perspect 107:207-217

Budziak D, Junior LR, Beltrame E, Carasek E (2007) Monitoring the formation of trihalomethanes in the effluents from a shrimp hatchery. Environ Monit Assess 127:435-444 Bull RJ, Birnbaum LS, Cantor KP, Rose JB, Butterworth BE, Pegram R, Tuomisto J (1995) Water chlorination: Essential process or cancer hazard? Fund Appl Toxicol 28:155-166 Bruchet A, Rousseau C, Mallevialle J (1990) Pyrolysis-GC-MS for investigating high-molecularweight THM precursors and other refractory organics. J Amer Water Works Assoc 82:66-74 Carlton JT (1987) Patterns of transoceanic marine biological invasions in the Pacific Ocean. Bull Mar Sci 41:452-65

Chang EE, Lin YP, Chiang PC (2001) Effects of bromide on the formation of THMs and HAAs. Chemosphere 43:1029-1034

Cowman GA, Singer PC (1995) Effect of bromide ion on haloacetic acid speciation resulting from chlorination and chloramination of aquatic humic substances. Environ Sci Technol 30:1624

Fabbricino M, Korshin GV (2005) Formation of disinfection by-products and applicability of differential absorbance spectroscopy to monitor halogenation in chlorinated coastal and deep ocean seawater. Desalination 176:57-69

Ged EC, Boyer TH (2014) Effect of seawater intrusion on formation of bromine-containing trihalomethanes and haloacetic acids during chlorination. Desalination 345:85-93

Globallast IMO (2015) Ballast water as a vector. London, United Kingdom: International Maritime Organization. http://globallast.imo.org/ballast-water-as-a-vector/ Gregg M, Rigby G, Hallegraeff, GM (2009) Review of two decades of progress in the development of management options for reducing or eradicating phytoplankton, zooplankton and bacteria in ship's ballast water. Aquat Invasions 4:521-565 
IMO (2016) International convention for the control and management of ships' ballast water and sediments London, United Kingdom: International Maritime Organization. http://www.imo.org/en/About/Conventions/ ListOfConventions/Pages/International-Conventionfor-the-Control-and-Management-of-Ships'-Ballast-Water-and-Sediments-(BWM).aspx. Accessed 9 Sep 2016 IMO (2008a) Guidelines for approval of ballast water management systems (G8). London, United Kingdom: International Maritime Organization. http://globallast.imo.org/wpcontent/uploads/2015/01/G8-GUIDELINES-FOR-APPROVAL-OF-BALLAST-WATERMANAGEMENT-SYSTEMS.pdf . Accessed 7 Dec 2015

IMO (2008b) Procedure for Approval of BWM systems that make use of Active Substances (G9) London, United Kingdom: International Maritime Organization. http://globallast.imo.org/wpcontent/uploads/2015/01/G9-PROCEDURE-FOR-APPROVAL-OF-BALLAST-WATERMANAGEMENT-SYSTEMS-THAT-MAKE-USE-OF-ACTIVE-SUBSTANCES.pdf. Accessed 7 Dec 2015

Liu Y, Thornton, DC, Bianchi TS, Arnold WA, Shields MR, Chen J, Yvon-Lewis SA (2015)

Dissolved organic matter composition drives the marine production of brominated very shortlived substances. Environ Sci Technol 49:3366-3374

Madabhushi BS (1999) What are trihalomethanes? On Tap, Spring 1999, 18-19

http://www.nesc.wvu.edu/ndwc/articles/QandA/OTsp99_Q_A.pdf. Accessed 9 Sep 2016

Paim APS, Souza JB, Adorno MAT, Moraes EM (2007) Monitoring the trihalomethanes present in water after treatment with chlorine under laboratory condition. Environ Monit Assess 125:265-270

Paolucci EM, Hernandez MR, Potapov A, Lewis MA, MacIsaac HJ (2015) Hybrid system increases efficiency of ballast water treatment. J Appl Ecol 52:348-357

Singer PC (1999) Humic substances as precursors for potentially harmful disinfection byproducts. Water Sci Technol 40:25-30

Stack MA, Fitzgerald G, O'Connell S, James KJ (2000) Measurement of trihalomethanes in potable and recreational waters using solid phase micro extraction with gas chromatographymass spectrometry. Chemosphere 41:1821-1826

Symons JM, Krasner SW, Simms LA, Sclimenti M (1993) Measurement of THM and precursor concentrations revisited: the effect of bromide ion. J Am Water Works Ass 85:51-62

Werschkun B, Banerji S, Basurko OC, David M, Fuhr F, Gollasch S, et al. (2014) Emerging risks from ballast water treatment: The run-up to the International Ballast Water Management Convention. Chemosphere 112:256-266

Werschkun B, Sommer Y, Banerji S (2012) Disinfection by-products in ballast water treatment: an evaluation of regulatory data. Water Res 46:4884-4901

Zhang N, Ma B, Li J, Zhang Z (2013) Factors affecting formation of chemical by-products during ballast water treatment based on an advanced oxidation process. Chem Eng J 231:427-433 Zhao R, Lao W, Xu X (2004) Headspace liquid-phase microextraction of trihalomethanes in drinking water and their gas chromatographic determination. Talanta 62:751-756

Zimmer-Faust AG, Ambrose RF, Tamburri MN (2014) Evaluation of approaches to quantify total residual oxidants in ballast water management systems employing chlorine for disinfection. Water Sci Technol 70:1585-1593 